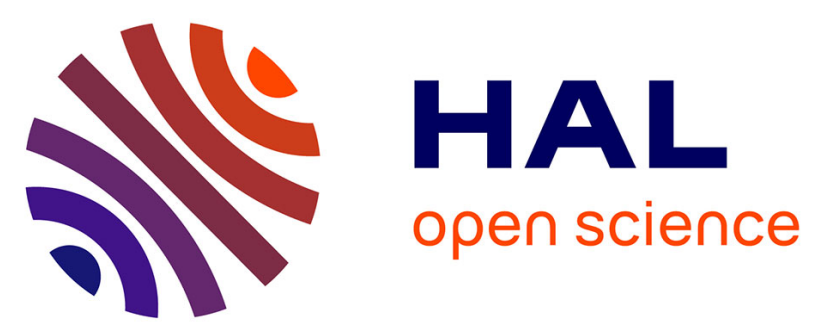

\title{
SYNTHESIS, CHARACTERIZATION AND CRYSTALLIZATION OF THE AMORPHOUS IRON (III) FLUORIDE : FeF3, xHF (0, 4 x 1)
}

G. Ferey, Jean-Marc Greneche, A. Le Bail, F. Varret, R. de Pape, J.

Pannetier, Marc Leblanc

\section{To cite this version:}

G. Ferey, Jean-Marc Greneche, A. Le Bail, F. Varret, R. de Pape, et al.. SYNTHESIS, CHARACTERIZATION AND CRYSTALLIZATION OF THE AMORPHOUS IRON (III) FLUORIDE: FeF3, xHF (0, 4 x 1). Journal de Physique Colloques, 1985, 46 (C8), pp.C8-175-C8-179. 10.1051/jphyscol:1985824. jpa-00225167

\section{HAL Id: jpa-00225167 https://hal.science/jpa-00225167}

Submitted on 1 Jan 1985

HAL is a multi-disciplinary open access archive for the deposit and dissemination of scientific research documents, whether they are published or not. The documents may come from teaching and research institutions in France or abroad, or from public or private research centers.
L'archive ouverte pluridisciplinaire HAL, est destinée au dépôt et à la diffusion de documents scientifiques de niveau recherche, publiés ou non, émanant des établissements d'enseignement et de recherche français ou étrangers, des laboratoires publics ou privés. 


\title{
SYNTHESIS, CHARACTERIZATION AND CRYSTALLIZATION OF THE AMORPHOUS IRON (III) FLUORIDE : FeF ${ }_{3}, x H F(0,4 \leqslant x \leqslant 1)$
}

\author{
M. Leblanc, G. Ferey, J.M. Greneche*, A. Le Bail, F. Varret ${ }^{\star}$, \\ $R$. de Pape and $J$. Pannetier ${ }^{\star \star}$ \\ Laboratoire des Fluomures, UA 449, Faculté des Sciences, \\ 72017 Le Mans Cedex, France \\ *Laboratoire Mössbauer, UA 807, Faculté des Sciences, \\ 72017 Le Mans Cedex, France \\ **Institut Laue Langevin, 156x, 38042 Grenoble Cedex, France
}

Résumé - Un nouveau fluorure amorphe $\mathrm{FeF}_{3}, \mathrm{xHF} \quad(0.4<\mathrm{x}<1)$, obtenu par réaction de $\mathrm{HF}$ gazeux sur $\mathrm{FeCl}_{3}$ à $80-100^{\circ} \mathrm{C}$ pendant $20 \mathrm{~h}$, est mis en évidence. La perte de $H F$, qui intervient au dessus de $100^{\circ} \mathrm{C}$, et la cristallisation en $\mathrm{Rh}-\mathrm{FeF}$ a vers $250-300^{\circ} \mathrm{C}$, ont été suivies par ATG, ATD, diffraction de neutrons et spectroscopie Mossbauer. Un essai de modélisation de l'amorphe $\mathrm{FeF}_{3}, \mathrm{xHF}$ est proposé à partir du spectre de rayons $x$ à $20^{\circ} \mathrm{C}$. Il conduit à un arrangement, en doubles feuillets de type ReO $\mathrm{O}_{0}$, d'octaèdres $\mathrm{FeF}_{6}$ déformês qui s'accorde bien avec la cristallisation de $\mathrm{FeF}_{\mathbf{a}}, \mathrm{xHF}$ en $\mathrm{Rh}_{-\mathrm{FeF}}$.

Abstract - A new amorphous fluoride $\mathrm{FeF}_{3}, \mathrm{xHF}(0.4<\mathrm{x}<1)$, obtained from the reaction of gaseous $\mathrm{HF}$ with $\mathrm{FeCl}_{3}$ at $80-100^{\circ} \mathrm{C}$ during $20 \mathrm{~h}$, is evidenced. The HF loss, above $100^{\circ} \mathrm{C}$, and the crystallization to $\mathrm{Rh}-\mathrm{FeF}$, were characterized by DTA, TGA, neutron diffraction and Mossbauer spectroscopy. An attempt to modelize the structure is proposed. The model, built from double $\mathrm{ReO}_{3}$ type layers of $\mathrm{FeF}_{6}$ octahedra, is in good agreement with the crystallisation of $\mathrm{FeF}_{3}, \mathrm{xHF}$ to $\mathrm{Rh}-\mathrm{FeF}_{3}$.

\section{I - INTRODUCTION}

Several amorphous iron fluorides are known : $\mathrm{FeF}_{\mathbf{a}} / 1 /, \mathrm{FeF}_{3} / 2 /, \mathrm{NaFeF}_{4}$ and $\mathrm{KFeF}_{4}$ /3/. All of them are prepared from high-temperature vapor deposition on a cold substrate. No attempt was made to use chemical reactions at very low temperature, leadding sometimes to poorly crystallized or amorphous materials.

We report here the synthesis, the characterization and the crystallization of a new amorphous iron(III) fluoride: $\mathrm{FeF}_{3}, \mathrm{xHF}(0.4<\mathrm{x}<1)$, obtained from a " soft chemistry " reaction.

\section{I - SYNTHESIS, CHEMICAL AND THERMAL ANALYSES}

A gaseous $\mathrm{HF}$ flow is passed in a monel tube over crystalline Fecla, held in a gold boat. The reaction is achieved after 20 hours at $80-100^{\circ} \mathrm{C}$ and $10-15 \mathrm{~g}$ of a bejge powder can be obtained at one time. Care must be taken to avoid the presence of moisture. The HF content of the material slightly differs from one experiment to another; several results of chemical analyses are reported in Table 1 . Then, the chemical composition can be preferably expressed as $\mathrm{FeF}_{3}, \mathrm{xHF}(0.4<\mathrm{x}<1)$. No trace of iron(II) is evidenced, by contrast with the vapor deposits of amorphous iron fluorides precedently described /2,3/. The TGA and DTA curves appear in Fig. 1. The weight loss of sample 1 is approximately $12.3 \%$ between the room-temperature and $467^{\circ} \mathrm{C}$; the estimate $\mathrm{x} \sim 0.8$ can be given. The theoretical weight loss corresponding to one $\mathrm{HF}$ per FeF molecule is $15.0 \%$.

Table I - Chemical analyses (weight \%) of $\mathrm{FeF}_{3}, \mathrm{xHF}$.

$\begin{array}{lcccc} & \text { Sample 1 } & \mathrm{FeF}_{3}, \mathrm{HF} & \text { Sample 2 } & \mathrm{FeF}_{3}, 0.4 \mathrm{HF} \\ \mathrm{Fe} & 42.2(1.4) & 42.04 & 46.1(1.5) & 46.21 \\ \mathrm{~F} & 56.7(2.3) & 57.20 & 52.9(2.1) & 53.45\end{array}$



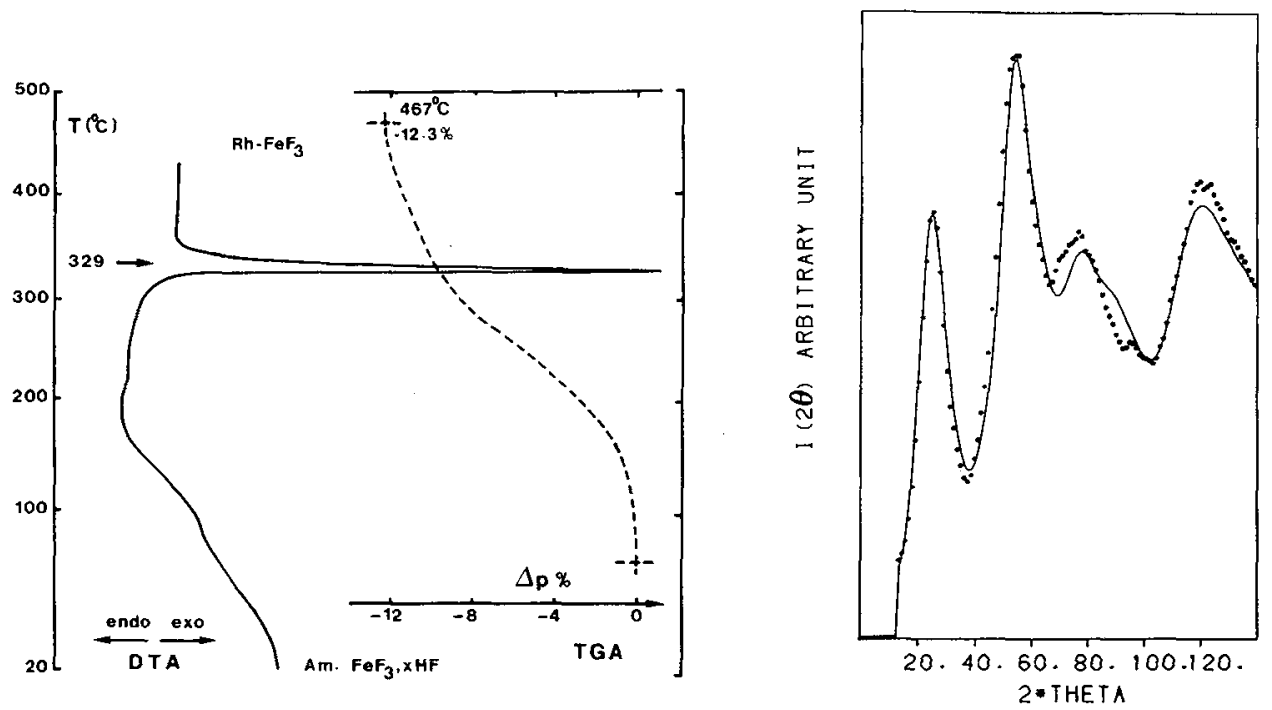

Fig. 1 - Thermal analysis of $\mathrm{FeF}_{3}, \mathrm{xHF}$ ( heating rate: $300^{\circ} \mathrm{C} / \mathrm{h}, \mathrm{N}_{e}, \mathrm{P}=1 \mathrm{Atm}$, Fig. 2 - Observed (dots) and calcula Du Pont 9900). ted (line) reduced interference functions of $\mathrm{FeF}_{3}, \mathrm{xHF}(\mathrm{Cu} \mathrm{K \alpha}, 293 \mathrm{~K})$.

\section{II $-\mathrm{X}$-RAY, NEUTRON AND MOSSBAUER CHARACTERIZATION.}

The X-ray ( $\lambda$ CuKa) (Fig. 2) and neutron $(\lambda=2.518$ A) diffraction spectra of FeF, $x$ HF, at room-temperature clearly evidence the amorphous state of the material: only diffuse scattering is observed.

At room-temperature, the Mossbauer spectrum consists of a doublet with broad lines (Fig. 3). The data are fitted with a distribution of Lorentzian quadrupolar doublets centered around the mean value $I S=0.48 \mathrm{~mm} . \mathrm{s}^{-x} *$. The quadrupolar splitting distribution is given at Fig. 3b. At low temperature, the freezing of the spins extends over 10 degrees around $36 \mathrm{~K}$. These two points corroborate the existence of an amorphous phase; the isomer shift is consistent with a six-fold coordination of $\mathrm{Fe}^{3+}$. It must

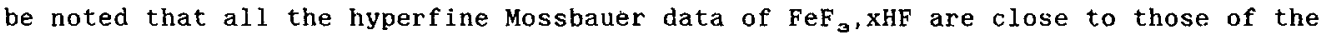
amorphous vapor deposited $\mathrm{FeF}_{3} / 2,4 /$.

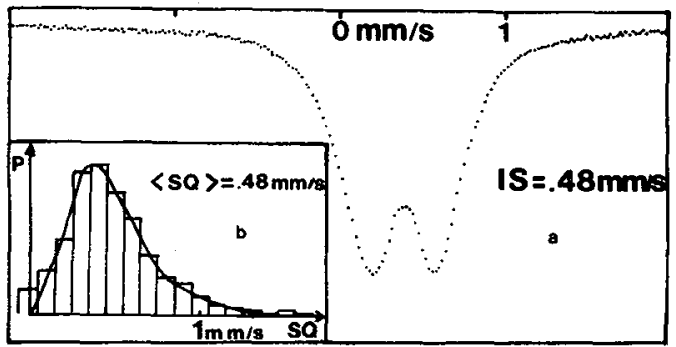

Fig. 3-a- Mossbauer spectrum of FeF, xHF at $295 \mathrm{~K}$,

-b- distribution of the quadrupolar splitting. 


\section{IV - CRYSTALLIZATION}

The heating of the amorphous $\mathrm{FeF}_{3}, \mathrm{xHF}$ leads to the formation of the crystalline Rh$\mathrm{FeF}_{3} / 5,6 /$. The crystallization was followed by TGA, DTA (Fig. 1), neutron diffraction (Fig. 4) and Mossbauer spectroscopy (Fig. 5).

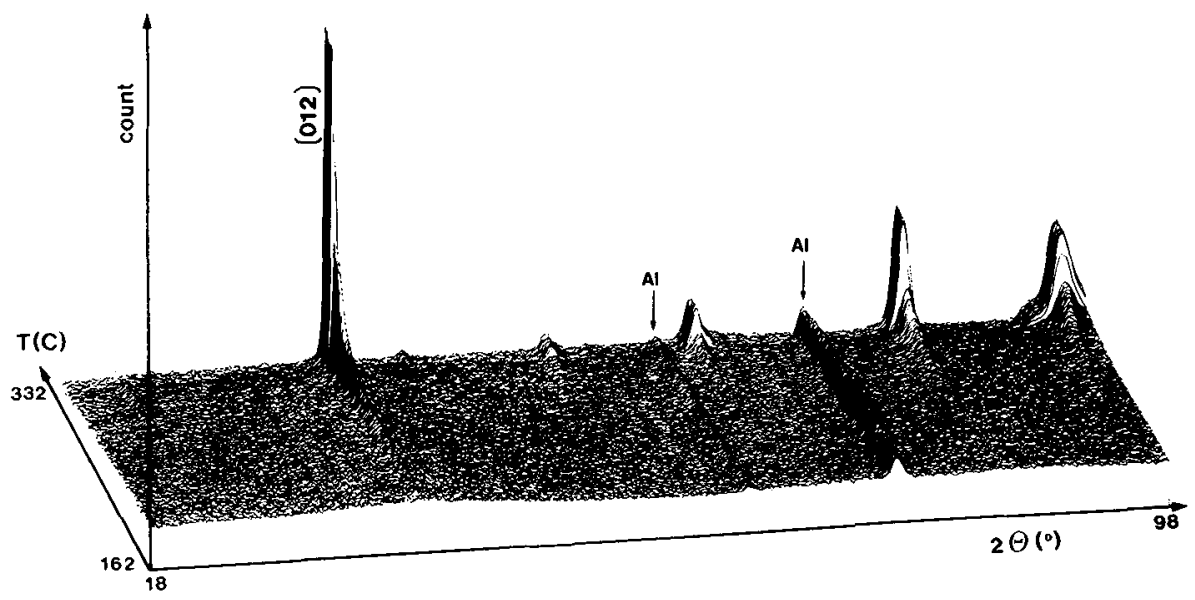

Fig. 4 - Temperature evolution of the transformation Am. FeF,$x H F==>$ Rh-FeF 3 under vacuum $\left(\lambda=2.518 \mathrm{~A}, \Delta t=6 \mathrm{mn}, \Delta \mathrm{T}=1^{\circ} \mathrm{C}, \mathrm{D} 1 \mathrm{~B}\right.$ (ILL Grenoble)).

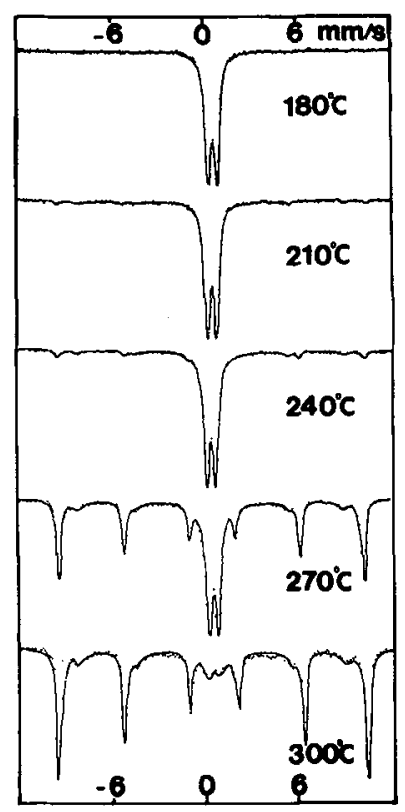

Fig. 5 - Mossbauer spectra obtained at $77 \mathrm{~K}$ after annealing $\mathrm{FeF}_{3}$, xHF at the mentionned temperatures during 6 hours under vacuum.

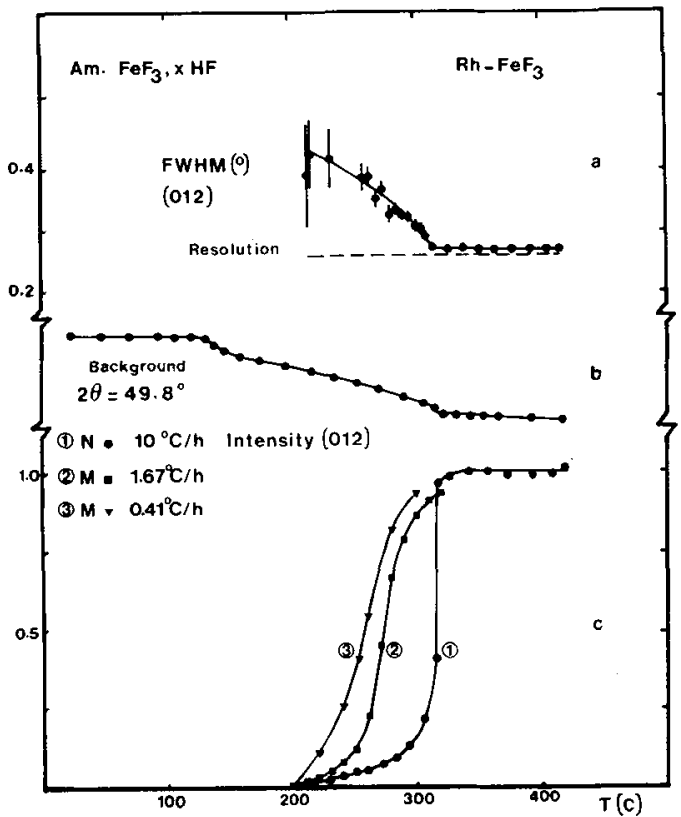

Fig. 6 - Background (b), intensity (c) and linewidth (a) of the (012) reflection in Fig. 4 (neutron spectra: N); Rh-FeF ate from Mossbauer experiments (M). 
The variations of the rate of crystalline Rh-Fef are obtained :

- from the intensity, scaled to 1.00 at $T>320^{\circ} \mathrm{C}$, of the more intense (012) line of $\mathrm{Rh}-\mathrm{FeF}$ (hexagonal cell of $\mathrm{R} 3 \mathrm{C}$ ) in the neutron spectra;

- from the analysis of the Mossbauer spectra (Fig. 5) of samples quenched at $77 \mathrm{~K}$ after annealing at increasing temperatures during constant time intervals.

It is concluded that :

- the loss of HF, revealed by TGA or DTA (Fig. 1) and background variation of the neutron spectra (Fig. 6b), is endothermic and occurs above $100^{\circ} \mathrm{C}$. TGA shows that the HF lass is not still complete after crystallization (Fig. 1);

- the crystalization of $\mathrm{Rh}_{-} \mathrm{FeF}_{3}$ is exothermic (estimated to $10 \mathrm{kcal} . \mathrm{mole}^{-1}$ );

- both effects take place over large overlapping temperature ranges, depending on the experimental conditions. The temperature, corresponding to the maximum rate of $\mathrm{Rh}-\mathrm{FeF}$, formation, decreases with the heating rate: $316^{\circ} \mathrm{C}$ at $10^{\circ} \mathrm{C} / \mathrm{h}, 270^{\circ} \mathrm{C}$ at i. $67^{\circ} \mathrm{C} / \mathrm{h}$ (curves 1 and 2 respectively in Fig. $6 \mathrm{c}$ ).

\section{V - MODELLING}

An attempt to modelize the structure of this new amorphous compound $F_{e} F_{3}$, xHF is described, using the quasi-crystalline method proposed in section A19 of this conference $/ 7 /$.

The structural types commonly encountered for $M F_{3}$ or $A M F_{4}$ compounds ( $A=$ alcaline, $M=$ transition metal) were tested : hexagonal tungsten bronze $/ 8 /, \mathrm{Rh}_{-\mathrm{FeF}} / 6 / \mathrm{TlAlF}_{4}$ /9/ or $\mathrm{KFeF}_{4} / 10 /$ and pyrochlore /11/ types. After refinement of positional and cell parameters, only one model, deriving from the Reo type, gives satisfactory results between calculated and observed interference functions (Fig. 2) (SG: $P-1, R=0.054=$ $\left(\Sigma \text { (Iobs-Ical }^{2} / \Sigma \text { Iobs }^{2}\right)^{1 / 2}$. The final atomic positions and pseudo-cell dimensions are given in Table II (hydrogen atoms were not located). A projection of the model along b appears at Fig. 7 .

of course, this model has to be understood as the best mean local atomic arrangement able to reproduce the $x$-ray interference function and its Fourier transform. The simulated and experimental reduced atomic distribution functions are compared (Fig. 8) and the agreement factor is $R=0.174=\left(\Sigma(\text { Gobs }- \text { Gcalc })^{2} / \Sigma \text { Gobs }{ }^{2}\right)^{2}{ }^{2}$.
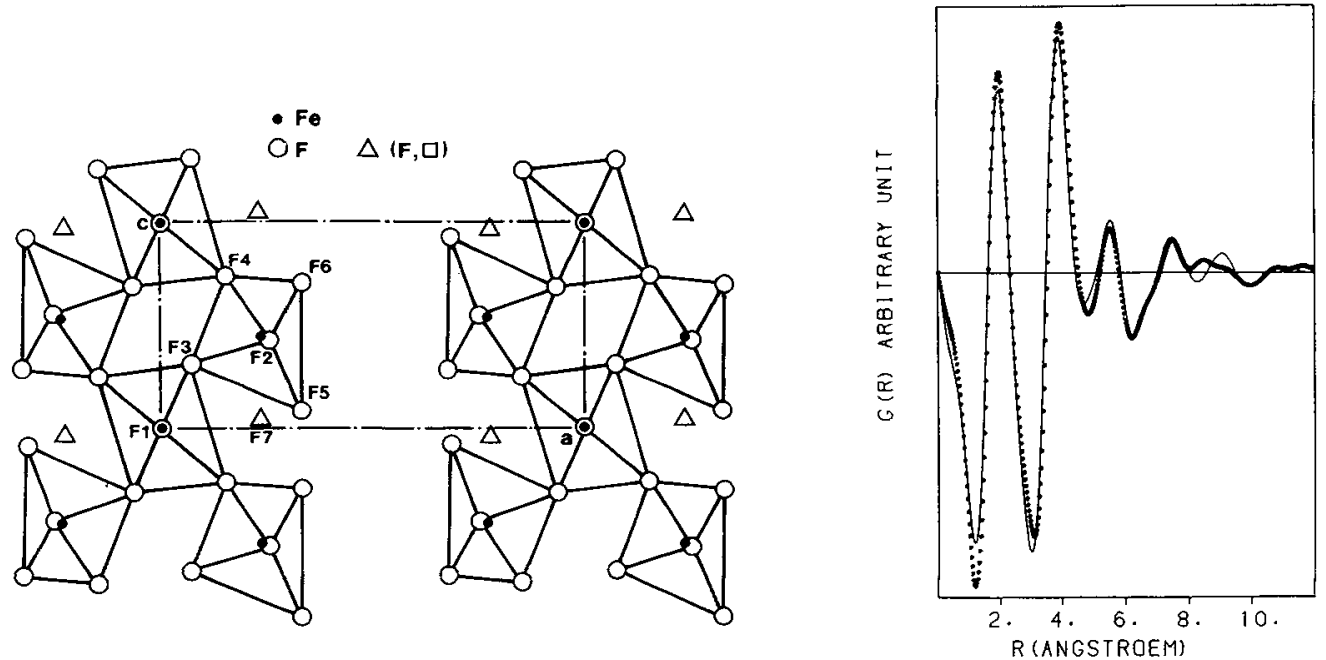

Fig. 7 - Representation of the model of the amorphous FeF, $\mathrm{xHF}$
Fig. 8 - Observed (dots) and calculated (line) reduced atomic distribution functions $\mathrm{G}\left(\mathrm{r}\right.$ ) of $\mathrm{FeF}_{3}, \mathrm{xHF}$ (Cu Ka, $293 \mathrm{~K}$ ). 
Table II - Structural parameters of $\mathrm{FeF}_{3}, \mathrm{xHF}$ in the quasi-crystalline method (e. s. d. in parentheses)

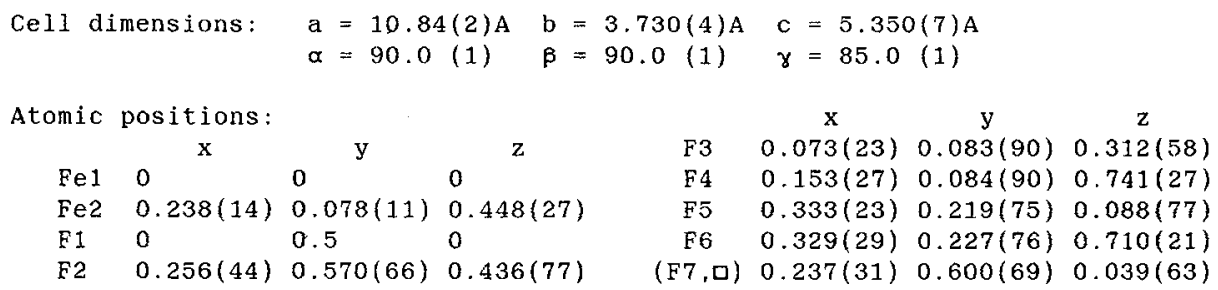

Mean distances: $\langle\mathrm{Fe} 1-\mathrm{F}\rangle=1.986 \mathrm{~A}\langle\mathrm{Fe} 2-\mathrm{F}\rangle=1.932 \mathrm{~A} \quad\langle\mathrm{Fe}-\mathrm{F}\rangle=1.95 \mathrm{~A}$

VI - CONCLUSION

This new amorphous $\mathrm{FeF}_{3}, \mathrm{xHF}$, synthetized by "soft chemistry" reaction, crystallizes

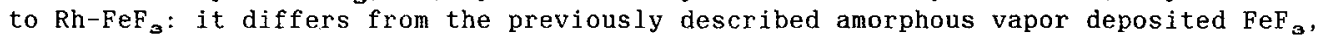
crystallizing mainly to $\mathrm{HTB}_{\mathrm{A}} \mathrm{FeF}_{\mathbf{3}}$.

A modelization of $\mathrm{FeF}_{3}, \mathrm{xHF}$ is proposed, using a quasi-crystalline method. The model consists of separated double layers $\mathrm{Fe}_{\mathrm{S}_{1}} \mathrm{~F}_{\text {: it }}$ is figured out that the $10 \mathrm{ss}$ of $\mathrm{HF}$ molecules (corresponding to F5 or F6) allows to link the layers, in order to build the framework of corner-sharing octahedra in $\mathrm{Rh}^{-\mathrm{FeF}} \boldsymbol{s}$.

So, it is of interest to correlate the above structural results with the mechanism of formation and growth of $\mathrm{Rh}-\mathrm{FeF}_{3}$ particles. From this viewpoint, a kinetic study is undertaken by Mossbauer spectroscopy and neutron diffraction. A line profile analysis, suggested by the linewidth variations (Fig, 6a) in the neutron spectra, will be performed.

\section{REFERENCES}

/1/ Litterst, F. J., J. Physique Lett. 36 (1975) L-197.

/2/ Ferey, G., Leclerc, A. M., De Pape, R., Mariot, J. P. and Varret, F., Solid State Commun. 29 (1979) 477.

/3/ Ferey, G., Coey, J. M. D., Henry, M., Teiliet, J., Varret, F. and Buder, R., J. Mag. Mag. Mat. 15-18 (1980) 1371.

/4/ Eibschutz, M., Lines, M. E., Van Uitert, L. G,, Guggenheim, H. J. and Zydzik, G. J., Phys. Rev. B29 (1984) 3843 .

/5/ Hepworth, M. A., Jack, K. H., Peacock, R. D. and Westland, G. J. Acta Crystallogr. 10 (1967) 63.

/6/ Leblanc, M., Pannetier, J., Ferey, G. and De Pape, R., Rev. Chim. Miner. 22 (1985) 107 .

/7/ Le Bail, A., Jacoboni, C. and De Pape, R., Section A19, Int. Conf. on the Structure of Non-Crystalline Solids, Grenoble (1985).

/8/ Magneli, A., Acta Chem. Scand. 7 (1953) 315.

/9/ Brosset, C., Anorg. Allgen. Chem. 239 (1938) 301.

/10/ Heger, G., Geler, R, and Babel, D., Solid State Commun. 9 (1971) 335.

/11/ Babel, D., Pausewang, G, and Viebahn, W., Z. Naturforsch. 22b (1967) 1219.

/12/ Lopez-Herrera, M. E., Varret, F., Calage, Y. and Ferey, G., J. Mag. Mag. Mat. 44 (1984) 304 . 